\title{
E-learning in Library and Information Sciences in \\ Cameroon: skill development, occupational integration and problems of visibility: Case Study.
}

\author{
Balock Née Ngo Kobhio Louise Lutéine \\ University of Yaoundé II-Advanced School of Mass Communication, Cameroon
}

\begin{abstract}
While university-level face-to-face training in Library and Information Sciences dates back to the 1990s in Cameroon, e-learning training is lagging considerably behind in terms of take-off. However, results obtained in this discipline by former e-learning learners concerning skills development, vocational integration, or self-employment are encouraging. The observation of the career path of a promotion of former e-learning learners at the Yaoundé Advanced School of Mass Communication is an example. There is diversity in the professional of the academic profiles of the learners at the time of registration. Their motivations are also multifaceted in relation to the choice of training and show that the skills acquired can be useful regardless of professional status or area of activity.But training in this field in e-learning mode in Cameroon still poses many problems, namely the visibility of the training structure among the public. Some institutions and social groups still need to know the usefulness of having welltrained personnel in Library and Information Sciences. As far as the visibility of training structures is concerned, communication tools such as the mass media are not the only means to prioritise. The sociological characteristics of the cameroonian environment requires face to
\end{abstract}


face. For, it is often a question of convincing some social actors or companies to adopt this mode of training. The study, which is partially based on experience and practice offers tools and means that can provide better visibility to the training structure such as a guide of partnerships and suggestions for setting up networks involving the participation of various actors.

Keywords: E-learning, Library and Information Sciences, Cameroon-skills development, occupational integration, Perception of e-learning, Visibility.

\section{Introduction}

Educating or training are the means of transmitting knowledge and techniques. Although faceto-face training has been in the early school years the means of education for people in Cameroon since the $1960 \mathrm{~s}$, this country has also gradually moved towards e- learning through Information and Communication Technologies, to meet the very diverse needs of its population. More specifically, since the 2000s, Cameroonian universities have undertaken studies on the generalisation of e-learning. But this initiative did not have a real impetus until 2010.

The advantage of this type of training is that it does not necessarily imply the permanent presence of students on campus. In addition, it helps to limit infrastructural problems such as the construction of new premises. For Cameroon, as Onguene Essono asserts(2010), it is all about diversifying the opportunities, involving all stakeholders, but also implementing innovative and unconventional offers of higher education.

This study is based on e-learning, which is defined as a training system that relies on the use of information and communication technologies for the transmission of knowledge and techniques. It is an educational system based on the web. The following definition summarises in a few words the challenges of e-learning: "E-learning can be defined as the use of computer and internet technologies to deliver a broad array of solutions to enable learning and improve performance" (Kavitha \& Lohany, 2019). Al-lozi, Kattoua \& Alrowad (2016) add that "Information technology is one of the most fundamental forces for change in all sectors of our lives" nowadays. The acquisition and development of skills using specific technological tools is called for in this undertaking. 
Consequently, the significant contribution of this training approach to development in Cameroon, having regard to the impact it can have on the professional path of learners in Library and Information Sciences (LIS) should not to be neglected. Moreover, the perception by institutions or undertakings of these occupations, which are quite new in the Cameroonian educational environment, namely librarianship, documentation and records management, may also be modified in this way. The corpus used to serve as an application to this reflection is the observation of the career path of former LIS learners at ASMAC (Advanced School of Mass Communication), at the University of Yaoundé II. The analysis also identifies the contextual obstacles to be overcome to implement this training because of their visibility and importance in the context of vocational integration after training.

\section{Statement of the problem}

One of the major challenges Library and information sciences (LIS) in Cameroon is the training of a sufficient number of qualified personnel in this sector. For example, in 2014, out of 435 people working in 7 library networks, 67 or $15.4 \%$ benefited from higher education in librarianship, 79 or $18.2 \%$ were trained on the job and 289 were untrained or $66.43 \%$ (Zemengue, 2019). This is a challenge that has not yet been fully addressed, despite the efforts undertaken since the 1990s in higher education. To reach this goal, it is important to set up training structures in LIS, which take into account the expectations of populations with specific needs such as workers or people geographically distant from traditional training structures. This means that, in addition to face-to-face training, the university provides for Elearning that admits candidates who, for various reasons, cannot take face-to-face training. This group also includes candidates who wish to reorient their professional project alongside another activity or to strengthen their skills in the field of LIS.

The LIS professions are still poorly known or not sufficiently appreciated at their fair value in Cameroon by several social stakeholders in view of the challenges related to development. Acquisition of collections or processing relevant information, results in an increase in competitiveness or efficiency of the services concerned. Well-trained staff makes the contribution to the productivity or efficiency of the library, documentation centre or archive of the organisation more visible. e-learning is sometimes considered second chance or secondorder training in Cameroon, although the Covid-19 pandemic is increasingly putting this training on the agenda. Work to change attitudes is still needed, as is an adequate organisation to reach all social strata in Cameroon. The major challenge lies in the fact that this mode of training facilitates the increase in the number of qualified persons on the job.A stronger 
representation of professionals is a force action for the profession. Indeed, Stueart R.D. (2000) showed the important and decisive role played by information services in Asia, with regard to information management in a period of economic crisis.

The above remarks rise to a number of investigations such as: What are the academic profile and the status of e-learning learners in LIS ? What are their motivations at registration? What are the benefits of training in terms of skills development and job integration ? Which suggestions can be made to improve the e-learning environment in LIS and the visibility of the institutions for potential learners, partners and undertakings?

The goal is, on the one hand, to enable higher education institutions to have a better knowledge of the target groups and their motivations, in order to organise the communication particularly in favour of this public. On the other hand, the aim is to show social and economic actors the impact of e-learning in LIS on the development of skills and occupational integration.

These questions lead to the following hypothesis:

-Learners motivations are first based on professional perspectives.

- Registration also stems from personal, sociological and economical motivations.

-E-learning In LIS promotes skills development and facilitates occupational integration in that domain.

-It enhances the standing of the profession and offers a better visibility and perception of the contribution of this training method in the undertakings

The plan adopted for this study consists of four main parts: The literature review; the methodology; the study of the results of the survey of former e-learning learners in LIS at the Advanced School of Mass Communication (ASMAC) in Yaoundé and a discussion.

\section{Literature review}

The literature review focuses on four main points: e-learning and skill development; the obstacles to e-learning; the means to change the social perception of e-learning; and tutoring as an essential device to the formation.

1.1 E-learning and skill development: overcoming geographical distance and promoting learning. 
The developing countries, particularly those in sub-Saharan Africa such as Cameroon, have been increasingly confronted over the past few years with an influx of requests in higher education. In 2018, statistical data indicated that Cameroon had 230 higher education institutions and 520,000 students compared to 500,000 in 2016 (Cameroon-tribune, 2016). Debora Lésel (2019) proposes the renewal of pedagogical tools as a mean of access to a greater number of candidates and very diverse audiences to higher education in Africa. These include the use of information and communication technologies.

In a study on the trends in research on e-learning, based on 248 articles published between 2009 and 2018, Valverde-Berrocoso , Burgos-Videla , Garrido-Arroyo\& Morales-Cevallo (2020)show that the concept of E -learning has great potential from an educational perspective and contributes to sustainable development. The analysis of literature produced in this field also shows that the emphasis is placed on higher education. Generally, the training needs in LIS of people already involved in working life in Cameroon are real because many positions are not yet filled with qualified staff (Zemengue, 2019). This gap is an obstacle to the competitiveness of enterprises. To offer the opportunities other than face-to-face training fights against unemployment by promoting self-employment and creativity, which are important factors in economic and social development.

Authors like Sangra, Vlachopoulos \& Cabrera (2012) noted in a study that four viewpoints are involved in the definition of e-learning. They include elements that constitute the benefits of this model. The first is "technology driven, that is the use of technology to deliver learning and training programs. The second is "delivery system oriented". In this case electronic means are used to deliver a learning, an education program, or a training. The third is "communication oriented". The emphasis is laid here on the interactions between learners, teachers or peers through digital means. The last one is "educational paradigm oriented" that is the information and communication technologies are used to support students and to improve the learning. A training structure may choose to give priority to one aspect or another in his teaching methods.

The form of e-learning adopted depends on the situations studied in advance by the institution. Duhl \& Arora (2017) have identified four types of e-learning: fully online course, partially online course, wraparound model, and integrated model. In the first case, almost all courses and activities take place online. The wraparound model 'relies on study materials, which may comprise online study, guides activities and discussion 'wrapped around existing previously published resources such as textbooks or CD-ROM". In the integrated model, there are 
opportunities for computer conferencing, online learning activities in group, as well as online assessment of learning outcomes. It is very close to fully online learning.

e-learning therefore promotes greater interaction between the two groups involved, namely teachers and the learner. The latter exercises control over his environment and his pace of work. He can reconcile it with other occupations and organise his working time as he wishes. These characteristics explain why e-learning is a training method that is often suitable for organisations. A significant number of e-learning learners are working at the same time in a trade and are coming to improve their knowledge and skills in their field of work. Helen Nneka Eke writes: "Electronic learning is considered to be adequate method for training of human resources of contemporary organizations and companies; due to the advantages it offers" (2011). Anita Singh \& Lata Bajpai Singh have carried out a study in a student environment show that students are often in favour of e-learning because of its vocational orientation. They write: "easy to use and occupation oriented, transfer of skills and knowledge flexibility in lrarning influence students in adopting e-learning course"(2017).Another study by Anita Singh \& Surabhi Singh (2021) highlights the benefits of e-learning, which are based on the flexibility of training and the development of skills.

There may be a risk of dispersion, however, training programmes are often designed so that the learner acquires the skills required for the relevant training period. Thus, Kumbhar one can read : "E-learning is arranged to develop skills which are needed at the particular time" (2009).

The use of technological tools makes it possible to overcome the geographical distance between the training structure and the learners. Indeed, learners from geographical areas far from the present training structures can dialogue directly with teachers. All these advantages are a boon for developing countries like Cameroon, which see their field of action widened. But there are some challenges to address.

\subsection{An increasing method of formation: obstacles to be overcome}

A survey conducted by T. Unwin (2008) in 10 countries in Africa on e-learning showed that several countries in Africa such as Senegal and Cameroon were still in their infancy with regard to the number of training platforms. However, African countries in a general way were aware of the considerable contribution that E-learning could make to their respective education systems, as 68\% of respondents said. Christian Depover \& François Orivel (2012) also show that in a decade between 2000 and 2010, the E-learning landscape has evolved in 
Africa. In Black Africa, in the field of LIS, one can mention particularly the creation of the FORCIIR Project in 2002 in which Cameroon was active. This is a step forward that has contributed to the promotion of e-learning in LIS and related professions.

The implementation of LIS training projects in e-learning has often encountered many difficulties in developing countries. The first is the social recognition of this sector. It is right that authors such as Sandra Hirsch, Debbie Faires, \& Alice Hines conducting a study on the feasibility of an e-learning project in LIS in Vietnam insist on the need to know the cultural context in which one finds oneself. This approach allows to better understand the difficulties that actors may face and the ways to get around them. They write, "A successful transition to an E-learning model is dependent upon the attitudes of its key stakeholders groups towards elearning, as well as the technological and pedagogical readiness for the transition" (2018). It is the general situation in Black Africa.

Nneka Eke-Okpala (2011) faces the same challenges related to this poor perception of elearning in LIS Nigeria. The difficulties encountered by distance learning structures are quite similar from one African country to another. Authors like Collin \& Karsenti (2011)point out the poor perception of E-learning in a general way by certain social groups.

Much is to be done to change the perception of the public of LIS training: to have evidence of the employability of diplomas, to discern from a sociological point of view what the target groups expect from a university education or after training. The target audiences are potential learners, actors of all kind1 who can provide support to the undertaking, that makes it possible to value E-learning in the information sciences. In Cameroon, experience shows that to achieve this goal, it should be given a significant place to face to face with social actors to present the training and its benefits. The stakes are high when it comes to the emergence of corporations that recognise the value of the professionals in information sciences.

The other obstacles are related to the flexibility regarding the time of submission of homework or exams for those who work, the possibility or not to be able to take registration from his place of residence, or a good connection to the Internet. It also underlines the need for strong interactivity towards those who come from other specialisations; so they should be well supervised.

\subsection{Possible solutions to change the perception of e-learning.}

It is possible to work on changing the public perception of e-learning. This process is based on the competitiveness of the learners and their employability. In order to reach the target 
groups, which are made up of a wide range of social and economic actors, the training structure should know and give priority to the means of communication they use.

Participation of public authorities is very important because they can act as the basis of the education system. Thus, some recommended methods to give greater visibility to the development of e-learning in a general way can be adopted. They have shown their effectiveness in other places. The aim is to get students accustomed to the use of information and communication technologies for their learning at an early age. This allows them to change their mentality with E-learning. Cameroon has implemented initiatives in this direction in education as shown by some authors like Fonkoua (2011), or Ngamo \& Karsenti(2015).

A study conducted by Kisanjara,Tossy \& Sife (2017) show that when students are involved in e-learning training at the same time as face-to-face, they develop skills more easily and have little difficulty in adopting e-learning.Authors such as Rejitha; Radhika; \& Meena Zenith conclude in a study : "There is $98.1 \%$ relationship between challenges faced to adopt Elearning technologies and use of E-learning technologies in education" (2020). They also show in the same analysis where it is $92 \%$ for the good perception of e-learning.

The recent adoption of E-learning in today's global context can contribute more than ever to raising the profile of Library and information sciences in Cameroon and Africa. This statement is all the more relevant since new paradigms are regularly emerging in this discipline which is at the crossroads of others. It is the foundation upon which other areas of knowledge construct to develop. Moreover, it is constantly attuned to the evolution of technologies and knowledge that it uses for its concerns.

\subsection{Tutoring: an essential device to reinforc learners motivations.}

Authors such as El-Seoud S.A,El Eddin, \&El Khouly M.M.(2015) have studied the student motivations in e-learning. They assert that those motivations can be " intrinsic" or "extrinsic".The first is described as an inner force that enables the learner to surpass himsel. The second relates to the prospect of immediate or differed gain.They are personal, sociological or economic.

Effective tutoring hels to support the different motivations. Tutors assist teachers and play a pivotal role in the training. The tasks assigned to them vary according to the choices of the institutions. They embody the human and relational dimension of learning devices . They are in charge of the management of interactions between learners and teachers on the one hand, and responsible for fostering exchanges between learners on the other hand. In some 
structures, especially small ones, teachers perform this function at the same time as teaching activities. This allows them at the same time, especially in the first years of implementation of the system, to test the relevance of the content. The term accompaniment increasingly tends to replace the term tutor, which in some contexts may have a negative connotation.

One can distinguish four models of implementation of the tutoring function: Functional, affective, pedagogical and holistic models as shown by Depover \& Glickman (2011). The functional model focuses on didactic and methodological support. The psychological and motivational aspect is very marked with the affective model. The educational model emphasises a wide range of meta-cognitive and methodological activities. Finally, the holistic model takes into account all the difficulties faced by learners. What is important is to be able to adapt the tutorial offer to the multiplicity of needs that may arise. The ideal tutor is ultimately a training facilitator in every sense of the word. Collin \& Karsenti (2011) studied the problems encountered by distance learning in Africa based on surveys carried out among learners enrolled in those formations. They point out that overall, the role of the tutor is well perceived.

\section{Methodology}

This study is partially based on observation and experience. To this end, It addresses aspects such as the usual profiles of learners, the places and the possibilities of meeting with the target audiences, i.e. prospecting, the importance of tutoring; the creation of networks and the implementation of partnerships necessary to the visibility of the structure. The analysis also looks at the sociocultural obstacles that may arise.

A survey with former trainees from e-learning in LIS on the subject is included in the study. The results obtained by these learners after the training, about professional integration constitute a centerpiece in the negotiation with partners and the recruitment of new learners. The aim is to show the contribution of e-learning in LIS to the recognition of the jobs concerned, and the need to put in place strategies to ensure the implementation and success of this method of training, which contributes significantly to the transmission of knowledge and know-how. The analysis of the contents of the courses, the sources of funding for training, or the equipment are not treated in this study, and should form the basis of another reflection.

The corpus chosen for learners is a promotion that corresponds to an entity. The choice was for a promotion where all learners are reachable and the career path is well known. Moreover, 
that sample is representative of the diversity of situations observed with the situation and the vocational integration of the learners. An online questionnaire was sent to these former learners, coupled with two-way telephone interviews to have a closer contact with them. (See Appendix). The survey took place from August 2020 to December 2020.

The questionnaire included questions on:

- Occupational status (Current and at the time of registration): Worker or job seeker.

- The channel used to become aware of the existence of the training.

- The discipline or area of specialisation at the time of registration.

- The reasons for integrating training.

- The benefits of training: at the professional level, promotion, etc. (See appendix).

As far as interviews are concerned two main questions were asked: what former students could say about the tutoring they received. The data of the study are essentially qualitative.

\section{Results}

\subsection{An institutional environment favourable to initiative.}

The survey conducted by E-learning Africa (2020) shows Cameroon's interest in e-learning. Indeed, the survey indicates that 15 African countries, including Cameroon, out of the 52 respondents, have fed this reflection by producing $73 \%$ of responses obtained. This shows that there is a willingness on the part of the government and the institutions concerned to take part in exchanges on this subject with a view to resolving problems related to the introduction of Information and Communication Technologies in education at all levels. Ngiewih Teke (2012) also presents the efforts made by the Cameroonian Ministry of higher education in this era.

When containment is set for 17 March 2020, and higher education institutions must reflect on how to implement training platforms, many lecturers of ASMAC are already trained in online course placement and related requirements. They had been initiated to several training courses for teachers since 2002 as part of the international cooperation generated by the FORCIIR project in LIS, then in collaboration with the AUF which is the University Agency for Francophonie, to continuously train all lecturers.

The first E-learning training structure in Library and information sciences in higher education in Cameroon dates from 2002 under the name of the Forciir Project (Formation Continue en Informations Iinformatisées en Réseau=Continuing training in Network Computerised 
Information). It was set up as part of international cooperation initiated by the French Ministry of Cooperation. It results from the agreement between the University of Yaoundé II and ASMAC on the one hand, and the French Ministry of Cooperation on the other.

This training was based on the e-doc-Dev training project initiated by the Cheikh Anta Diop University in Senegal and more specifically in EBAD (Ecole des Bibliothécaires Archivistes et Documentalistes). The desire to develop South-South cooperation in the field of distance learning. Countries such as Morocco and Madagascar were involved in the project. In Cameroon, a training called CEMIDE (Certificat en Management de 1' Information et des Documents dans 1' Entreprise), which means certificate in management of information and documents in enterprises .The level required was Master I. At the end of training, the student is a design worker executive in the trades related to LIS with a good mastery of ICTs. The first batch in Cameroon begins in 2003.

Later on, in 2006, in response to the demand of the workers, candidates who are bachelor's degree holders with at least two years of experience in the course of their activities were to be admitted. The structure will run continuously until 2018. Previously, since 2008, the project had been backed by the Department of Archives Library and Information Science. A Total of 178 learners have been formed in the two divisions from 2003 to 2018 (statistics of the formation).Studies are being carried out to design a new model of the training organisation. With the advent of the pandemic, new issues related to the management of the pandemic have emerged. The aim is to train lecturers and students more regularly in the use of the training platform set up. That is why lecturers in ASMAC use both the online training platform and face to face teaching.

Several training seminars for teachers and students have been organised in this direction since the beginning of 2020.These activities constitute permanent laboratories that keep the main players in training in contact with the ICTs. Several opportunities for E-learning-type training in LIS should be offered to Cameroonian universities. In addition, the necessity to give them good visibility in an educational and socio-professional environment is essential where this specialisation is not represented. Four Universities in Cameroon train students in this field: the University of Yaoundé II, the University of Dschang, the Protestant University of Central Africa and the University of Buéa. All have implemented an asynchronous method of training with ICTS or in an online training platform or other. Reflections are initiated on the implementation of e-learning. 
The implementation of an e-learning training structure in LIS requires a good knowledge of the profiles of the usual candidates, their motivations, and the means to reach them and interest them in training. So what are the characteristics of learners who are involved in elearning in LIS?

\subsection{Talking to former learners.}

\subsubsection{Academic and Professional profiles of learners: their motivations.}

Generally speaking, most candidates for e-learning training in LIS at this level are already employed. Many already work in libraries, documentation centres, and archives. The same goes for the corpus studied.

The selected batch consists of 21 graduates of the CEMIDE, the graduating batch of 2014 . They are specialised at the time of their registration in the following disciples: Letters, Law, Economics, Political Science, Librarianship and Documentation, Archive Science and Records Management, Education Science.

Enrolment in this training comes from the desire to acquire skills in the professions of documentary information namely: Librarianship, Documentation, Archive Science, and Records Management. The details below provide an overview of the different situations that led to their registration. Diverse motivations are mentioned according to the situation of each learner.

Table I: Learners motivations.

\begin{tabular}{|c|c|}
\hline \multicolumn{2}{|c|}{ Stated Motivations } \\
\hline $\begin{array}{c}\text { I am a techno-pedagogical Advisor by training.I } \\
\text { wanted to live up to the position that had just } \\
\text { been assigned to me in the Department of } \\
\text { Documentation and Archives of the Ministry } \\
\text { where I am employed. }\end{array}$ & $\begin{array}{c}\text { I am an employee of a university. I have learned about } \\
\text { this training through my institution. Being often } \\
\text { confronted with collections developement or documents } \\
\text { management I thought that this training could help me } \\
\text { in my daily work. }\end{array}$ \\
\hline $\begin{array}{c}\text { There was no skilled labour to manage the } \\
\text { archives in the bank where I still work. } \\
\text { Acquiring the skills to organise and manage my } \\
\text { company's documents was my goal. It was } \\
\text { achieved. }\end{array}$ & $\begin{array}{l}\text {-I needed vocational training in one area to find a good } \\
\text { job. My choice is focused on this area and bears fruit. }\end{array}$ \\
\hline $\begin{array}{c}\text { I wanted to master the process of organisation } \\
\text { and processing both physical and digital of our } \\
\text { documentary heritage, given the } \\
\text { mismanagement and the lack of effective } \\
\text { management of the mass of paperwork in our } \\
\text { families and our society. }\end{array}$ & $\begin{array}{l}\text { An assignment in the Documentary Information Service } \\
\text { sparked my interest in this training. I preferred to take } \\
\text { this training in this field to better serve the users } \\
\text { instead of on-the-job training which, in my opinion, was } \\
\text { not very profitable. I also benefited from the } \\
\text { encouragement and financial support of my directorate. }\end{array}$ \\
\hline
\end{tabular}




\begin{tabular}{|c|c|}
\hline $\begin{array}{l}\text { I was interested in the training. I am a } \\
\text { bachelor's degree holder in LIS obtained } \\
\text { through e- learning in the same structure in. I } \\
\text { decided to perfect my knowledge. }\end{array}$ & $\begin{array}{l}\text { I am a journalist by training. I was convinced that } \\
\text { acquiring skills in this field, which is part of the } \\
\text { information and communication sciences, would help } \\
\text { me a great deal in my profession. I was right about that. }\end{array}$ \\
\hline $\begin{array}{l}\text { My motivation: to master the process of } \\
\text { organisation and processing both physical and } \\
\text { digital of our documentary heritage, in view of } \\
\text { the mismanagement and the lack of effective } \\
\text { management of the mass of paperwork in our } \\
\text { families and our society. }\end{array}$ & $\begin{array}{c}\text { There was no skilled labour to manage the archives in a } \\
\text { bank where I still work. Learning the skills to Organize } \\
\text { and manage documents was my goal }\end{array}$ \\
\hline $\begin{array}{l}\text { I used to work in the archives. I wanted to } \\
\text { acquire the required skills that I did not have in } \\
\text { the context of information management. }\end{array}$ & $\begin{array}{c}\text { I had a degree in history. I thought I would take a } \\
\text { vocational training course that was a little in line with } \\
\text { my initial training. The archival work was particularly } \\
\text { well suited to this }\end{array}$ \\
\hline $\begin{array}{l}\text { I was a few years away from retirement and I } \\
\text { wanted to return to another sector by taking a } \\
\text { vocational training course that could allow me } \\
\text { to be recruited into a company after my } \\
\text { retirement. The management of documents and } \\
\text { information in the company seemed to be the } \\
\text { appropriate training, all the more so since my } \\
\text { job essentially involved producing and } \\
\text { managing documents. }\end{array}$ & $\begin{array}{l}\text { I work for the police and I handle a lot of files. I had } \\
\text { difficulty organising my archives in such a way as to } \\
\text { find them easily. I jumped at this opportunity when I } \\
\text { realized that the skills I acquired will make my job } \\
\text { easier. Today I am satisfied. }\end{array}$ \\
\hline $\begin{array}{l}\text { I wanted to take a course in librarianship, } \\
\text { documentation and archival library science. } \\
\text { Given my other occupations, this mode of } \\
\text { training suited me well. }\end{array}$ & $\begin{array}{l}\text { I work in a university library. I didn't have adequate } \\
\text { training. When I became aware of this training, I } \\
\text { decided to register with the support of my manager. }\end{array}$ \\
\hline
\end{tabular}

Several types of motivation emerge from the analysis of responses given by former learners. A total of 14 candidates out of 21 or $66.66 \%$ are already on a job and find it difficult to do their daily work properly. There is also a desire to acquire additional training that is in line with their previous speciality. The aim to contribute from a social point of view to a better consideration of the management of documents or archives is expressed. Finally, the candidate for training may be in a process of reconversion. This may be due to the desire to practice in this field in the private sector after retirement. Also in this case, the choice concerns a sector which seems interesting and which, in addition, can be used to solve economic problems.

Furthermore, the possibility of reconciling training and other occupations is mentioned by all learners. The academic year included two face-to-face groups of one week each where the teacher presented the content of the courses, which were already available on the training 
platform. Continuous Assessments were done on the platform. Learners returned to present the face-to-face exams in one week each semester. The rest of the exchanges took place on the platform or by telephone. The learner could meet physically if necessary with the tutor or other training providers for any problems related to his training. In this case it is almost a fully online course because the ratio can be estimated at $85 \%$ of fully online course against $15 \%$ of face-to-face. A six month internship in a company is required for each learner.

\subsubsection{After training: some success stories.}

Former learners express Satisfaction with acquired skills in general, for, some of the representative statements made below show this.

\section{Table II- Training outcomes}

\begin{tabular}{|c|c|}
\hline \multicolumn{2}{|c|}{ Examples of training outcomes } \\
\hline $\begin{array}{c}\text { I am very comfortable now in my profession as a } \\
\text { librian }\end{array}$ & $\begin{array}{c}\text { Today I am satisfied. I do not regret the time spent } \\
\text { in this training. I am better at my job. }\end{array}$ \\
\hline $\begin{array}{c}\text { I managed to relieve the archives department } \\
\text { abandoned to itself in the banking structure where I }\end{array}$ & $\begin{array}{c}\text { I was able to convince a structure of the need to } \\
\text { create an archive service. I helped create a service } \\
\text { that did not exist in the company }(* 2)\end{array}$ \\
\hline $\begin{array}{c}\text { The hierarchy was very convinced by my new skills } \\
\text { acquired during the training. I was now able to } \\
\text { implement solutions to the information management }\end{array}$ & $\begin{array}{c}\text { After my training, I was recruited into a banking } \\
\text { structure where I had previously been an acting } \\
\text { intern. }\end{array}$ \\
\hline $\begin{array}{c}\text { My experience in archives management since the } \\
\text { end of my training has already been proven in } \\
\text { several structures. I have completely changed my } \\
\text { orientation because I am passionate about my new } \\
\text { profession (Former Political Science Training) }\end{array}$ & $\begin{array}{c}\text { I can organise my files more easily and I am more } \\
\text { efficient in my work }\end{array}$ \\
\hline $\begin{array}{c}\text { I was not wrong in choosing this profession at the } \\
\text { end of my initial career. I was able to integrate an } \\
\text { archive management project after retirement. }\end{array}$ & $\begin{array}{c}\text { My training was the way to get a promotion } \\
\text { ( } 6)\end{array}$ \\
\hline $\begin{array}{c}\text { I was able to find work in the liberal professions } \\
\text { sector as an archivist. My skills are very } \\
\text { appreciated }\end{array}$ & $\begin{array}{c}\text { Ijoined an archive management project after my } \\
\text { retirement. I can continue to be active in the field } \\
\text { that I am passionate about }\end{array}$ \\
\hline
\end{tabular}


More specifically, at the end of the training, six learners claim to have obtained promotion in companies or the institution of origin, because of their expertise now proven and a better mastery of the computer tool, that is to say, the increase in skills observed by their hierarchical superiors.

Ten of them say there has been an improvement in the management of archives and documentation in their institution. The latter, however, include three learners who deplore the fact that their firms that had financed their training, convinced of the merits of this initiative, did not then use all the financial means to organise archives worthy of the name. Their skills are nevertheless used as much as possible for the structure in their respective departments.

Two unemployed learners at the time of registration convinced institutions following their training to set up a service responsible for the management of administrative documents which were abandoned and were thus able to create their jobs. A learner who soon after also became a teacher in higher education say ; "I do not regret the time spent in this training because the knowledge acquired allows me to better organize my documents and my research. I conduct my research more efficiently than before. Moreover, I have sometimes been involved in small private companies where I contributed to the management of the archives ». Two learners are

looking for a more stable job. They have only been awarded fixed-term contracts.

\subsubsection{Perception of e-learning by learners}

All the learners interviewed felt that e-learning was a good initiative, especially in a training field that is not very widespread. They add that the Covid-19 context has provided greater visibility to e-learning, which is just as relevant as face-to-face training.

The term or idea of "flexibility" has come up in all their declarations in connection with training. In so far as the training structure receives managers from enterprises or persons whose activities are sometimes linked to structures of the highest administration, ASMAC has thought about solutions that do not penalise them considering continuous assessment for example. Someties a learner has to go on a mission suddenly in a context that does not allow him to concentrate on submitting their test at the same time as the others.there are some geographical areas where the internet connexion is not easy or available..In this case, the training makes him undergo on his return a test different from that of the others, in a concern of effective control of the knowledge. 
The principle adopted with tutoring being the holistic model is a practice that, in the opinion of the learners, allowed them to feel accompanied. A tutor was designated by class, however, in reality, the learners benefited from the guidance of all the teachers. The learner could easily benefit from advice on how to cope with school or social difficulties, which may hinder his training. All learners want to see more e-learning experiences across the country.

The survey also pointed out that a great deal of solidarity was created between learners of this promotion over the year. This was maintained after the training by creating an exchange platform that allows them to maintain the link and share their respective experiences. Such initiatives must be encouraged and strengthened because it also facilitates the re-identification of the former learners.

\section{Communicating with the public}

\subsection{Prospecting for target audiences}

To the question of how they heard about the training, the channels mentioned by 15 of them are the traditional mass media used by the institution, that is to say, radio, television, the press. But also the website of the ASMAC, the leaflets and the display, or by word of mouth towards the social groups that may be interested. These are elements of the communication mix that enable the target audiences to be reached. All these steps required visits to companies, communication with associations, training institutions in higher education, etc. Six of them refer specifically to informal channels, namely a friend, a colleague who has already completed this training, a student, a university teacher. This proves that word-of-mouth should not be neglected in the Cameroonian context. Informal channels must occupy a significant place.

Marketing studies show that the best piece of evidence is the product of the company in this case the former learners. Thus, Ventolini \& Mercier(2017) have shown the role and place of former learners in the promotion of training projects, especially when these networks provide resources in terms of the professional integration of graduates, the reputation and financial resources for the training institution. It has happened that an institution sends several people to training in ASMAC based on the assessment of the expertise acquired by other learners and their favourable opinion on training. Thus, thanks to these former learners, a certain mentality in companies sometimes presenting these trades as not being very profitable, gradually evolving towards a more accurate appreciation of their contributions to the development. 
Successful communication at the local and national level with organisations, companies etc., is a challenge that will face the E-learning structures in LIS in Cameroon. As the structure is dealing with a wide range of audiences, it is necessary to know their objectives and to prospect the specific needs of companies or institutions. This is a condition for better valuing the businesses concerned and their contribution to the performance of supervisory bodies.

To further increase the visibility of the structures, inventories should be made of institutions and undertakings, which may be interested in the national territory and by region. These must be contacted and grouped by centres of interest. Among the public institutions there are, for example, all the ministries with decentralised services in the regions, which constitute pools of recruitment. This involves close contact with the directorates responsible for human resources management, archives and documentation services. The regional and departmental delegations of these institutions are also to be explored. An organisation like the Inter patronal Groupment of Cameroun (GICAM) has opportunities to get in touch with companies.

\subsection{Importance of partnerships.}

It is important to establish a partnership in each region with other universities and higher education institutions. The partner institutions will set up recruitment centres. They will have to contact the regional authorities or any other institution or opportunity that presents itself. This will lead to the creation of a centralised network whose activities are coordinated by the university initiating the programme. The partner universities are responsible for supervising the examinations which may take place on a presential basis according to the choice of the institutions.

Of course, each ministerial department, for example, works with a set of structures attached to it. Partnerships can be established directly with the latter. There are also universities with several institutions and specialised structures. The nature of the agreement will be defined on a case-by-case study. Partnerships with organisations and associations are necessary, as the librarians associations, the enterprises or the Inter patronal groupment of Cameroon as well as institutions in the CEMAC sub-region should be enhanced. All the communication tools and means mentioned by former students in the environment and related to the sociological and cultural environment should be considered. 


\section{Discussion}

The outcome of the study shows that candidates can come from all social and economic categories. The learners' motivations appear to fall under three main objectives:

- The desire to better manage abandoned documents, whether at the social level or in the company.

- The desire to improve their skills in this field of activity. It is a matter of addressing a concern that of greater efficiency in the position occupied.

-The concern to prepare one's professional future or to reorient one's activities at the end of a career because of the opportunities that training holds.

The reasons for integrating training are above all related to the desire to acquire skills on the one hand, and master techniques applicable to a given workstation on the other. In almost all cases, the workstation is located in a document information service of an employer that is a company or government. The position may be created on the learner's initiative after training. The learner thus becomes an influencer in the company. The student can be self-employed after training in a liberal profession such as setting up a consulting firm.

In short, economic reasons related to looking for a job or changes of status, such as the prospect of retirement, are so-called "extrinsic" motivations. Other reasons are "intrinsic", of a personal or sociological nature, such as the desire to contribute to re-establishing a societal order in terms of the treatment of documents in society in general, as expressed by one learner. The skills acquired are not always used in an information service. However, the acquired know-how adds value and contributes to the visibility and usefulness of the techniques and skills of the professionals.

Beyond the diversity of motivations and the use of acquired knowledge, the purpose can be summarised in the term "performance", which refers to the mastery of tools and techniques that are the conditions for profitability at both personal and professional levels.

Direct communication with target audiences should take into account all these social groups. It should make use of the means of communication in use in the environment, ranging from word of mouth to the mass media. For more visibility, the creation of partnerships is an opportunity to encourage companies to motivate and financially support those of their workers who want to take training. 


\section{Conclusion}

The objective of this study was to investigate the academic profile and the status of e-learning learners in LIS, to discover their motivations at registration; to show the benefits of training in terms of skills development and job integration; and to suggest ways and means that can be applied to improve the e-learning in LIS in higher education and the visibility of the institutions for potential learners, partners and undertakings.

At the end of the analysis, it appears that potential learners come from different horizons, with diverse motivations. The most important is to acquire knowledge and techniques that can bring efficiency in information management. Tthe study also shows that this mode of training can contribute in a significant way because of its flexibility to the development of the skills of the personnel of various companies and to the reduction of unemployment through job creation and self-employment. It is therefore important that schools linked to this type of training. Partnerships and adequate communication tools and means can contribute to better visibility of training structures.

\section{References}

[1] Onguene Essono, L. M. (2010) .Cameroun: Formation à distance et Internet tous azimuts à l'Université. https://www.researchgate.net/publication/

[2] Kavitha, V., and Lohamy, R .(2019).A critical study on the use of artificial intelligence,elearning technology and tools to enhance the learners experience. Https://link.springer.com/article/

[3] Kattoua,T., Al-Lozi, M., and Alrowwad, A.(2016). A review of literature on e-learning systems in higher education. Journal of business management and economic research,7(5), 754-762.

[4] Zemengue, J (2014).Forming the system of training of librarystaff in the Republic of Cameroon. PhD Thesis, Belarusian state University of culture and arts.

[5] Stueart R.D. (2000).The economic crisis and other challenges in accessing sciences and technological information in Asia. 65 th Ifla Council and general conference. https://journals.sagepub.com/doi/10.1177/

[6]

ameroon-tribune. (2018). Données statistiques sur l'enseignement supérieur. CameroonTribune. 11 Septembre 2018. Https://www.cameroon-tribune.cm/article.html 
[7] Lésel, D.(2019). L'enseignement supérieur en Afrique: Etat des lieux et effectifs. https://www.lafriquedesidees.org/

[8] Valverde-Berrocoso J., Garrido-Arroyo MDC, Burgos-Videla, Morales-Cevallos M.B.. (2020) Trends in educational research about e- learning: a systematic literature review 2009- 2018. Sustainability, 12 (12): 12-23. https://ideas.repec.org/a/gam/jsusta/

[9] Sangra, A, Cabrera, N, and Vlachopoulos, D. (2012). Building an inclusive definition of e-learning: an approach to the conceptual framework. International review of research on open and distance learning 13 (2):146-158.

[10] Duhl I., and Arora, S. (2017). Online learning. International education and research journal, 3(8): 32-33. http://www.ierj.in/

[11] Nneka Eke , H.((2011). Modeling LIS students intention to adopt E-learning : a case from University of Nigeria, Nsukka. Available at :https://www.researchgate.net/publication/

Anita Singh \& Lata Bajpai.(2017).e-learning for employability skills: students perspective. https://pdf.sciencedirectassets.com.

Singh, A and Surabhi, S.(2021).Investigating digital learning media for skill development programmes. The online journal of distance education and elearning, 9(2), 237-246. https://www.tojdel.net/journals/tojdel/

[14] Kumbhar, R.(2009).Use of e-learning in library and information science education. DESIDOC journal of library and information technology, 29(29): 37-41.

[15] Unwin, T. (2008) Survey of E-learning in Africa based on a questionnaire survey of people on e- learning Africa database in 2007. https://ahero.uwc.ac.za/ indexphp.

Depover C., and Orivel, F. (2012). Les pays en développement à l'ère de l'e-learning. Paris: Unesco: Institut international de planification de l'éducation. http://www.iiep.unesco.org/fr/

[17] Hirsch, S., Faires D. and Hines, A. (2018).Perceptions and viability of launching LIS elearning programs in developing countrie: a vietnam case study. Https://www.igiglobal.com/chapter/perceptions.

[18] Karsenti, T, Collin, S, et al.(2011). Où va la distance ? Les FOAD leur dynamique et leur contribution en contexte africain. Available at: http://gilleskuitche.emonsite.com/medias/files/les-formations-ouvertes-a-distance-en-contexte-africainkarsenti-collin.pdf . 
[19] Fonkoua , P., Matchinda, B., et al. (2011) Intégration des TICs au processus enseignement apprentissage au Cameroun. Les cahiers du ROCARE-Cameroun et les éditions terroir. Https://searchworks.stanford.edu/view/.

[20] Tchameni Ngamo, S., and Karsenti, T .(2015). Intégration des Tics et typologie des usages :perception des directeurs et enseignants des grandes écoles secondaires du Cameroun. https://hal-amu.archives-ouvertes.fr/

[21] Kisanjara, S B, Tossy, T M, S. Sife, S.Msanjila. (2017). An integrated model for measuring the impacts of E-learning students. International Journal of education and development using information and communication technology, 13 (3): 109-127.

Radhika, R , Rejitha RS, and Meena Zenith, N. (2020).

Perception about E-learning and E-Learning usage in Triviandrum district. International Journal for Research in Applied Science and Engeneering Technology 8 (VIII), 13311335.

[23] El- Seoud, Taj Eddin IATF, El-Khouly M.M.(2015). How to keep learners motivates in an e-learning environment? Conference paper CFET 2015.4p. https://www.researchgate.net/publication/

[24] Depover C., Glickman V., et al. (2011). Le tuteur en formation à distance : un métier, une identité. In C. Depover, et al., le tutorat en formation à distance. https://www.cairn.info/

[25] Ngiewih Teke, C. (2012) .Digitalizing learning centents in Cameroon's higher education : towards standardization : a critical theory course site in the university of Yaoundé I.Bhatter college journal of multidisciplinary studies, 2 : 66-75.

[26] E-learning Africa. (2020).The effect of Covid 19 on education in Africa and its implication for the use of technology: a survey of the experience and opinions of educators and technology specialists. https://aisa.or.ke/resources/

[27] Ventolini, S. and Mercier, S. (2017). Le reseau d'anciens diplomés: une ressource stratégique pour les diplomés de l' Université? Finance, contrôle et stratégie, 20 (2): 120.

\section{Questionnaire of the survey}

This questionnaire was drafted as part of an academic research on e-learning structures in LIS in higher education.

Please answer the questions below. 


\section{I- Information on the respondent.}

-Job Seeker :

Yes/ No

- Currently employed :

\section{II-Training: .}

-In what year did you join the Foorciir Project Project?

- How did you obtain information about the existence of this structure?

- What was your level of education at the time of entry into ASMAC?

- What was your area of specialisation at the time of registration?

- What were your main motivations for integrating this training?

-Did your training at ASMAC provide you with a promotion in your professional activity?

- Did it promote your professional integration into a sector of activity? (Check the corresponding box).

-Yes/No

-If so, how?

- In your opinion, is e-learning increasingly a necessity in today's global context? Justify your answer.

Thank you for your collaboration. 